\title{
Labial fusion causing urinary incontinence: reply by the author
}

\author{
Ayhan Dirim
}

Published online: 8 July 2011

(C) The International Urogynecological Association 2011

\section{Dear Editor,}

Actually, stress urinary incontinence was the complaint of the patient on admission. The clinical picture, however, was overflow incontinence. That is why we did not mention any correction of stress incontinence; we just treated the overflow incontinence by relieving the obstruction [1]. It is clear that overflow incontinence may be described by a patient as stress inconti- nence, so a detailed history and diagnostic approach is mandatory.

\section{Reference}

1. Dirim A, Hasirci E (2011) Labial fusion causing urinary incontinence and recurrent urinary tract infection in a postmenopausal female: a case report. Int Urogynecol J 22:119-120. doi:10.1007/s00192-010-1205-2

This reply refers to the comment available at doi $10.1007 / \mathrm{s} 00192-$ 011-1496-y.

\footnotetext{
A. Dirim $(\bowtie)$

Department of Urology, Baskent University School of Medicine,

5. Sokak, No: 48,

Bahcelievler, 06490 Ankara, Turkey

e-mail: drayhan_dirim@yahoo.com
} 